\title{
A taxonomic revision of western Eupholidoptera bush crickets (Orthoptera: Tettigoniidae): testing the discrimination power of DNA barcode
}

\author{
GIULIANA ALLEGRUCCI I , B R UNO MASSA ${ }^{2}$, ALESSANDRA \\ TRASAT T I ${ }^{1}$ and VALERIO SBOR D O N I ${ }^{1}$ \\ ${ }^{1}$ Dipartimento di Biologia, Università di Roma Tor Vergata, Rome, Italy and ${ }^{2}$ Dipartimento di Scienze agrarie e forestali, \\ Università di Palermo, Palmero, Italy
}

\begin{abstract}
The genus Eupholidoptera includes 46 Mediterranean species distributed from Turkey to Greece, Italy and southern France. In the eastern part of its range, Eupholidoptera has been considered to consist of several distinct species, while in the Balkans and Italian peninsula only E. chabrieri has been recognized. However, the status of some Italian populations, confined to particular geographic areas, remains uncertain. To investigate the delimitation of the Italian taxa of Eupholidoptera, we performed both morphological and molecular analyses. Morphological analysis was carried out by considering diagnostic characters usually used to distinguish different taxa, such as the shape of titillators in males and the subgenital plate in females. Molecular analysis was performed by sequencing three mitochondrial genes: $12 \mathrm{~S}$ rRNA, $16 S$ rRNA, partially sequenced and the entire gene of coxl. Molecular markers were used to infer phylogenetic relationships among the Italian Eupholidoptera species and to reconstruct the historical processes that shaped their current geographic distribution. Results from both morphological and molecular analyses were used to revise the taxonomic arrangement of species. On the whole we were able to distinguish nine lineages of Italian Eupholidoptera, of which E. tyrrhenica sp.n. from Corsica is described as a new species.

This published work has been registered in ZooBank, http://zoobank.org/urn:lsid: zoobank.org:pub:EBD181A0-5263-4880-AC80-66F624506E3A.
\end{abstract}

\section{Introduction}

Understanding the delimitation of species is crucial for several fields of biology and ecology and is important for both biodiversity studies and for conservation issues. Genetic data are often used to infer different species on the basis of reciprocal monophyly. However, several studies show incongruence between species inferred by genetic and morphological characters. Species delimitation can be especially difficult at early stages of population divergence, when both morphological and molecular characters show low

Correspondence: Giuliana Allegrucci, Dipartimento di Biologia, Università di Roma Tor Vergata, via della ricerca scientifica, 00133 Rome, Italy. E-mail: allegrucci@uniroma2.it

[Version of Record, published online 30 August 2013] levels of differentiation. Indeed, for recently diverged species, lineage sorting can be incomplete, due to genetic drift and/or gene flow (Knowles \& Carstens, 2007).

One example of taxonomic uncertainty in recently diverged lineages is provided by bush crickets belonging to the genus Eupholidoptera Mařan (Orthoptera, Tettigoniidae; type species: Locusta chabrieri Charpentier) which is distributed in the Mediterranean area. Previously, Eupholidoptera species were assigned to Pholidoptera Wesmal and earlier they were classified in the genera Locusta, Thamnotrizon or Olynthocelis. Eupholidoptera is characterised by green or brown-olive coloration, with black and yellow spots, and the last abdominal tergite black. It was described by Ramme (1951) who omitted to establish the type species of the genus. For this reason, in accordance with the International Code of Zoological Nomenclature, the author of the genus became the first who designated the type species, namely Mařan (1953). 


\section{G. Allegrucci et al.}

Ramme (1951) included in the genus Eupholidoptera species in which males have the tenth abdominal tergite black, and with titillators in the genitalia characterized by thin, long and smooth branches. When the genus was described 20 species were recognised, but nowadays about 50 are known. They are mainly distributed in Greece, Turkey and the Middle East, but are present also in Italy, Switzerland, France, Slovenia, Croatia, Albania and Bulgaria. According to Çiplak et al. $(2009,2010)$ this genus has an aegeid origin, and its presence in peripheral areas - such as the Levant, Italy, France and Switzerland - is possibly due to later dispersal from the Aegeid plate in the mid-Miocene, and the later division of this into separate lands in the Tortonian, between 11.6 and 7.2 Ma.

Morphology is rather variable between species; most of them are clearly definable and the morphological phenotypes are overwhelmingly more diverse than the song (Heller, 2006). The songs emitted by species of this genus are very simple and rather monotonous (Çiplak et al., 2009, 2010), and consequently they do not help in species determination. In this genus and in general within Tettigoniinae, the shape of the titillators is one of the main diagnostic characters used to distinguish different taxa (Çiplak et al., 2009, 2010). Generally, species of Eupholidoptera are allopatrically distributed, although in some cases they can be also sympatric; however, syntopic records of different species have never been reported (Çiplak et al., 2009; B. Massa, personal observation).

Eastern Eupholidoptera species have been generally treated as distinct species, while taxa living in the Balkans and Italian peninsula have been classified as subspecies of E. chabrieri.

From a historical point of view, hypotheses of species delimitation for Italian Eupholidoptera species have been revised several times since the original species description. Costa (1863) described Tamnotryzon magnificum (a synonym of Eupholidoptera magnifica) based on specimens collected in the 'Calabria ulteriore', geographically matching 'Calabria greca', that is the southern part of the region, south of the Neto river (south Italy). In 1881 Targioni Tozzetti described Tamnotryzon brunneri (a synonym of Eupholidoptera brunneri) based on a single small-sized female from Maielletta (Abruzzi, central Italy). Ebner (1915) considered it a valid species of Eupholidoptera, while Baccetti (1959) established the synonymy Tamnotryzon brunneri $=$ E. chabrieri chabrieri . Nevertheless, Harz (1969) still listed E.chabrieri brunneri for the Abruzzi in Central Italy and, based on old references, also for Latium in central west Italy. Titillators depicted by Harz (1969) match very well specimens from north Italy belonging to E.chabrieri chabrieri (cf. fig. 61 of La Greca, 1959). Moreover, they are very similar both to those of a specimen from Abruzzi, that Baccetti (1959) and Massa (1999) identified as E.chabrieri chabrieri, and to those of all specimens from the Abruzzi cited by Nadig (1985: figs 52-59).

The first author to contribute to the systematics of Eupholidoptera in Italy was La Greca (1959), who examined the variability of the male subgenital plate, the tergum 10 and the titillators of taxa considered at that time subspecies of
E. chabrieri. On this basis La Greca (1959) described three new species, E.danconai, E. hesperica and E. garganica and subdivided E.chabrieri into four subspecies E.chabrieri chabrieri, E.chabrieri schmidti (Fieber, 1861), E.chabrieri bimucronata (Ramme, 1927) and E.chabrieri magnifica (Costa, 1863). In the latter taxon La Greca (1959) recognized specimens coming from Sila (north Calabria, south Italy) and Campania (south Italy).

However, the taxonomy of Italian taxa remained unclear and the nomenclatural arrangement adopted by different authors may be considerably different. Indeed, Willemse (1980) considered both E.garganica and E.schmidti subspecies of E.chabrieri and E.danconai subspecies of the Balkan E. megastyla (Ramme, 1939). On the other hand, Nadig (1985) observed that populations of E.chabrieri living south of the Alps, from Provence to Istria, show a west-east clinal change for some characters, including titillators. In particular, populations distributed between Provence and Bergamo Prealps show typical characters of E.c.chabrieri, populations in the Brescia Prealps show intermediate characters between E.c.chabrieri and E.c.schmidti, and populations living between Belluno, Giulie Prealps and Istria show typical characters of E.c.schmidti. Following Nadig (1985), while in E.c.chabrieri the lateral profile of titillators is straight and the median lobe of the subgenital plate of males is just sketched, in E.c.schmidti and E.c.usi Adamovic, 1972 (living on islets of the north Adriatic and in Dalmatia and synonymised with E.c.schmidti by Willemse, 1980), the lateral profile of titillators is evidently upcurved and the median lobe of the male subgenital plate is well developed. However, he considered these differences as diagnostic because they allow distinction between different populations.

Finally, Massa (1999) proposed that some Italian taxa should be treated as distinct species and Fontana et al. (2005) recognized the following: E.chabrieri, E. garganica, E. magnifica (including bimucronata as subspecies), E.hesperica, E. schmidti and E. megastyla danconai. They were treated as synonyms or subspecies of E. chabrieri by Çiplak et al. (2009), with the exception of E.hesperica. Finally, Massa et al. (2012) recognized Eupholidoptera c.chabrieri, E.c. brunneri, E.danconai, E.garganica, E.hesperica, E.m.magnifica, E.magnifica bimucronata and E.schmidti, distributed in different areas of Italy, generally not overlapping.

In order to attempt to unravel this complicated situation, we carried out a study on the Italian taxa both at morphological and molecular levels. The main objectives of this study are: (i) to infer the phylogenetic relationships of the Italian and Corsican Eupholidoptera, using molecular markers; (ii) to reconstruct the historical processes that shaped the current geographic distributions of the Italian Eupholidoptera species, using (a) well-assessed substitution rates previously considered for the same genes in Orthoptera species (Shapiro et al., 2006; Allegrucci et al., 2011), and (b) modern coalescent methods allowing the comparison between gene tree and species tree (Drummond et al., 2006); (iii) to revise the taxonomic arrangement of species, subspecies and synonymies based on both morphological and molecular characters. 


\section{Material and methods}

Taxon sampling, laboratory procedures and sequence alignment

Thirty populations belonging to ten species or subspecies of the genus Eupholidoptera from the Mediterranean region were sampled in this study (Table S1 and Fig. 1). In particular we considered: (i) seven populations of E. schmidti, four from Slovenia (SLV, KOZ, POD, PRI) and three from north-east Italy (MVG, SSQ and MMUs); (ii) one population of E. chabrieri from north-west Italy (IMP); (iii) six populations of E.danconai from north-east (MMUd, CAT, PIE) and central-south Italy (TRL, JEN, ROG); (iv) one population of E.c. brunneri from Abruzzi (south Italy, BRU);(v) three populations of E. magnifica from coastal Tuscany (SCA), Sardinia (ARB) and Calabria (SIL) and two populations from Corsica (BIG, OSP) belonging to the new species, here described, E.tyrrhenica sp.n.; (vi) two populations of E. garganica, one from Apulia (MAF) and one from Greece (LEF); (vii) one population of E. hesperica from Basilicata (south Italy, MAR) and (viii) four populations here assigned to E.bimucronata stat.n. (previously assigned to E. magnifica bimucronata) from Sicily (GIB, SAL, MAD, PTR). Three more taxa from Greece and Turkey were considered: E. uvarovi (KAS), E. smyrnensis (ALE, KOY, MRM) and E. megastyla (MTO). Two additional taxa belonging to two different genera were used as outgroups, Deracantha onos and Tettigonia vividissima. The sequences for these latter taxa were retrieved from GenBank (EU137664.1, Zhou et al., 2009, and EF540827, respectively).

Most specimens were obtained from private or museum collections, while a minor fraction were collected by one of us (B.M). Samples were collected between 1966 and 2011 and were preserved both in $90 \%$ ethanol or dried (Table $\mathrm{S} 1)$. Genomic DNA was isolated from leg muscle using two different standard purification kits of genomic DNA (GenElute Mammalian Genomic DNAMiniprep kit, Sigma-Aldrich, St Louis, MO, USA, and DNeasy Blood \& Tissue Handbook, Qiagen, New York, USA), resuspended in $200 \mu \mathrm{L}$ of sterile water, and stored at $-40^{\circ} \mathrm{C}$.

The entire Cytochrome Oxidase I gene ( $\operatorname{cox} 1$, total of $1500 \mathrm{bp}$ ), a 550-bp fragment of the $16 \mathrm{~S}$ rRNA gene and a 450bp fragment of the $12 S$ rRNA gene were amplified through the polymerase chain reaction (PCR) and sequenced from each individual. The large subunit of the nuclear ribosomal DNA (28S rRNA) was also included. The primers used were: LCO1490, HCO 2198 (Folmer et al., 1994), UEA1, UEA5 and UEA10 (Lunt et al., 1996) for the coxl gene, 12Sai, 12Sbi (Kocher et al., 1989; Simon et al., 1994) for the $12 S$ rRNA gene and 16Sar, 16Sbr (Simon et al., 1994 ) for the $16 S$ gene. With regard to $28 S$ rRNA, it was partially amplified and sequenced for a fragment of $580 \mathrm{bp}$, belonging to domains $3-5$, using primers from Friedrich \& Tautz (1997). Novel specific primer pairs were designed from conserved regions and used in nested PCR amplifications to obtain fragments from poorly preserved individuals (Table S2). Double-stranded amplifications were performed with a
Perkin-Elmer-Cetus thermal cycler in $25-\mu \mathrm{L}$ reaction volume containing genomic DNA (10-100 ng), $1.5 \mathrm{~mm} \mathrm{MgCl} 2,0.2 \mathrm{~mm}$ of each dNTP, $0.1 \mu \mathrm{M}$ primer, 1.5 units EuroTaq (Euroclone, UK) and buffer supplied by the manufacturer. The optimal cycling parameters varied for each primer pair used. PCR products were purified using the ExoSAP digestion (Amersham Pharmacia Biotech), directly sequenced in both directions using the BigDye terminator ready-reaction kit, and resolved on an ABI 3100 Genetic Analyzer (PE Applied Biosystems), following the manufacturer's protocols.

Each gene fragment $(12 S, 16 S$ and $\operatorname{cox} 1)$ was considered separately for the alignment. Sequences of $16 \mathrm{~S}$ and $12 \mathrm{~S}$ were aligned using CLUSTAL_X v1.81 (Thompson et al., 1997) with opening gap $=10$ and extending gap $=0.10$. Cytochrome oxidase I nucleotide sequences were assembled, aligned, and translated using Codon-Code Aligner v3.7.1. Sequences of $28 \mathrm{~S}$ rRNA were not considered in the subsequent analyses because they were not informative, being the same in all taxa. All sequences were submitted to Genbank (accession numbers are reported in Table $\mathrm{S} 1$ ).

\section{Data analysis}

\section{Phylogenetic analysis: gene tree estimation}

Phylogenetic analysis was carried out on the concatenated matrix, partitioned by genes. It was performed using both Bayesian and Maximum Likelihood (ML; Felsenstein, 1981) inferences as implemented by the software MrBayes v3.1b4 (Huelsenbeck \& Ronquist, 2001) and Treefinder (Jobb et al., 2004). Mrmodel test (Nylander, 2004) was used to perform hierarchical likelihood ratio tests and calculate approximate Akaike Information Criterion (AIC) values of the nucleotide substitution models for each gene fragment.

At least two simultaneous searches were conducted comprising four Markov chains started from a randomly chosen tree and run for 1000000 generations, with sampling every 100 generations. The following descriptors were assumed to indicate convergence on a common phylogenetic topology by separate Bayesian searches: similarity in log likelihood scores at stationarity, similarity in consensus tree topologies and PP values for supported nodes, and a final average standard deviation of split frequencies (ASDSF) for simultaneous searches approaching zero. The first 1000 trees were discarded as burn-in and posterior probabilities (PP) were calculated from postburn-in trees.

Bootstrap supports (BP) for the resulting ML topology were calculated using 500 replicates, as implemented in Treefinder.

\section{Species tree and divergence times estimation}

Although sequence data from separate genes are generally used to address and estimate the true species phylogeny (species tree), it is well known that gene trees can disagree with its containing species tree, due to errors in gene tree estimation, gene duplication and extinction, gene introgression and deep coalescence (Maddison, 1997; Edwards, 2009; 




Fig. 1. Sampling sites of Eupholidoptera populations used in the molecular analysis (see also Table S1).

Knowles \& Kubatko, 2010). To estimate the species tree we used a coalescent-based approach. In particular, we used *BEAST (StarBeast, Heled \& Drummond, 2010) method as implemented in BEAST (v1.7.4; Drummond et al., 2006; Drummond \& Rambaut, 2007). *BEAST operates under a Bayesian framework, jointly estimating the posterior distribution of species trees from the posterior distribution of individual gene trees using a coalescent model. *BEAST allows for gene tree heterogeneity, attributing gene tree/species tree discordance to deep coalescence. Populations were assigned to species, following the results from this study. In particular, Corsican populations were assigned to the new species E.tyrrhenica sp.n., and Sicilian populations were assigned to E. bimucronata stat.n.

*BEAST was also used to infer divergence times. We used a relaxed molecular clock, following an uncorrelated lognormal (UCLN) model of molecular evolutionary rate heterogeneity as implemented in BEAST (v1.7.4; Drummond et al., 2006; Drummond \& Rambaut, 2007). The UCLN model was used in BEAST to estimate the posterior density of divergence times. A Yule or 'pure birth' prior process was used for the branching rate in the phylogeny. The time to the most recent common ancestor (MRCA) between each clade was estimated under the models highlighted in MrModeltest (Nylander, 2004) for each partition within each gene. We performed four independent

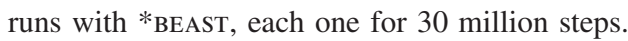

Convergence to stationarity and effective sample size (ESS) of model parameters were assessed using TRACER v1.5 (Rambaut \& Drummond, 2007), with the species tree reconstructed after a $10 \%$ burn-in using TreeAnNotator (v.1.7.4; Drummond et al., 2006; Drummond \& Rambaut, 2007).

Fossil evidence or adequate events of geological vicariance to calibrate the molecular clock are not available. Hence, to approximate absolute ages of divergence among haplotypes of Eupholidoptera, we applied the substitution rates reported in the literature for Orthoptera. In particular, the mean rate used for coxl in this study was $1.5 \%$ per site, per lineage per million year (Ma). This rate was obtained in Orthoptera Tettigoniidae from Hawai (Shapiro et al., 2006) using the time of the estimated split of the different islands. The mean rates used for $12 \mathrm{~S}$ and $16 S$ rRNA were 1.1 and $0.7 \%$ per site/lineage/Ma, similar to those calculated for Dolichopoda species (Orthoptera, Rhaphidophoridae) by Allegrucci et al. (2011). 


\section{Genetic diversity among Eupholidoptera species}

Genetic diversity between the different species of Eupholidoptera and within each of the analysed species was investigated by using the coxl gene (the first $648 \mathrm{bp}$ ) as a DNA barcode. We used only sequences from coxl to have a better control with data from literature. DNA barcodes are identified in short and standardized genomic regions that can discriminate morphologically recognized species (Hebert et al., 2003). Pairwise nucleotide sequence divergences were calculated using p-distance.

\section{Morphological analysis}

Morphological characters used were the subgenital plate and titillators of the male, as well as the shape of the subgenital plate of the female. The subgenital plate of the male is wide and divided into two parts by a deep median incision. Each part ends with a more or less evident process, generally with one or two spines of variable length. In addition, each part of the subgenital plate bears a stylus. Titillators have a central body with two straight or upcurved branches of variable length; the body is basally supported by two basal stick-shaped branches. We considered also the length of cerci compared to the length of tergum 10. Series of images of specimens with different focal planes were taken using a Nikon Coolpix 4500 digital camera, mounted on a Stereomicroscope Optech EMX-210-2, and were incorporated using the freeware CombineZM (Hadley, 2008). Measurements on mounted specimens (total length, length of pronotum, hind femora and ovipositor) were taken using a digital calliper (accuracy $0.01 \mathrm{~mm}$ ). Morphometric variables were initially analysed by multivariate analysis, using both PCA and discriminant analyses. Results suggested that the ordination of samples was strongly influenced by the size of considered variables with individuals grouped together according to their size and regardless of the species they belong to. Therefore, we performed a cluster analysis to obtain Euclidean distances among species. Material examined for morphological analysis is listed in File S1.

\section{Results}

Taxonomic issues and gene tree analysis

Based on both morphological and molecular analysis we recognized a new species of Eupholidoptera from Corsica: E.tyrrhenica sp.n. We also have raised the status of E. magnifica bimucronata, endemic to Sicily, to species level, calling it E. bimucronata stat.n. (see also section on morphological results).

The Bayesian analysis produced a consensus topology highly congruent with that obtained by ML analysis (Fig. 2). Eupholidoptera uvarovi from Turkey resulted as the most differentiated species and the Greek species E. smyrnensis and E. megastyla clustered as sister taxa of the Italian species. Within the Italian species two main groups could be identified, the first one comprising the eastern species and the second one the western and Apennine species. The eastern group included four clades constituted by populations belonging to E. schmidti, E. garganica and E.chabrieri. Populations from Slovenia formed a robust clade $(\mathrm{PP}=0.92, \mathrm{BP}=0.93)$ that is the sister group to populations of E. schmidti coming from other sites in Slovenia and to populations from Marche region (on the Adriatic side of the Italian peninsula). Linked to these clades are the populations of E. garganica from Apulia and Greece $(\mathrm{PP}=1 ; \mathrm{BP}=0.99)$. Finally, E. chabrieri, represented by one population from Liguria, in north-west Italy, was the sister species to the eastern group of species (Fig. 2; $\mathrm{PP}=\mathrm{BP}=1$ ).

The strongly-supported western and Apennine group of species (Fig. 3; $\mathrm{PP}=0.94 ; \mathrm{BP}=0.99$ ) included five clades, each represented by the five analysed taxa, i.e. E.danconai, E.hesperica, E.bimucronata stat.n., E.magnifica and E.tyrrhenica sp.n. Each clade was strongly supported but their relative relationships were unresolved both in Bayesian and likelihood analyses. The Corsican populations (BIG, OSP) belonging to E. tyrrhenica sp.n., were strongly linked ( $\mathrm{PP}=1$; $\mathrm{BP}=0.99$ ) to the Sicilian ones (belonging to E. bimucronata stat.n.).

\section{Species tree analysis}

*BEAST analyses resulted in a strong supported tree identifying the analysed species. Italian species formed a cluster subdivided into two clades, one comprising eastern species $(\mathrm{PP}=0.94)$ and the other including western and Apennine ones $(\mathrm{PP}=0.93)$. The relationships between E.hesperica, E. magnifica and E.bimucronata stat.n. are not resolved (Fig. 51).

\section{Divergence times}

Dating estimates indicated that radiation within the in group occurred from 1.7 Ma (Fig. 51). The Coxl gene showed a nonclock-like behaviour, with a coefficient of variation of 0.720 (95\% High Posterior Density, HPD: 0.466-0.992). Both $12 S$ and $16 S$ showed a coefficient of variation of $0.01(95 \%$ HPD: $1.5 \mathrm{E}-4$ to 0.03 for $12 S$ and $1.4 \mathrm{E}-4$ to 0.03 for $16 \mathrm{~S}$ ). We found any evidence of autocorrelation of substitution rates in any of the datasets (mean covariance: $-0.035,95 \%$ HPD:-0.192/0.133 for cox1, -0.009, 95\% HPD:-0.197 to -0.173 for $12 S$ and $-0.011,95 \%$ HPD: -0.194 to 0.179 for $16 S)$.

\section{Genetic diversity among Eupholidoptera species}

Using the first $648 \mathrm{bp}$ of coxl gene as barcode and p-distance, we carried out a genetic distance analysis between all populations belonging to the ten species of Eupholidoptera analysed in this study. We excluded E.c.brunneri from analysis because we failed to amplify the target genes. The mean observed genetic distances ranged from 0.003 to 0.017 


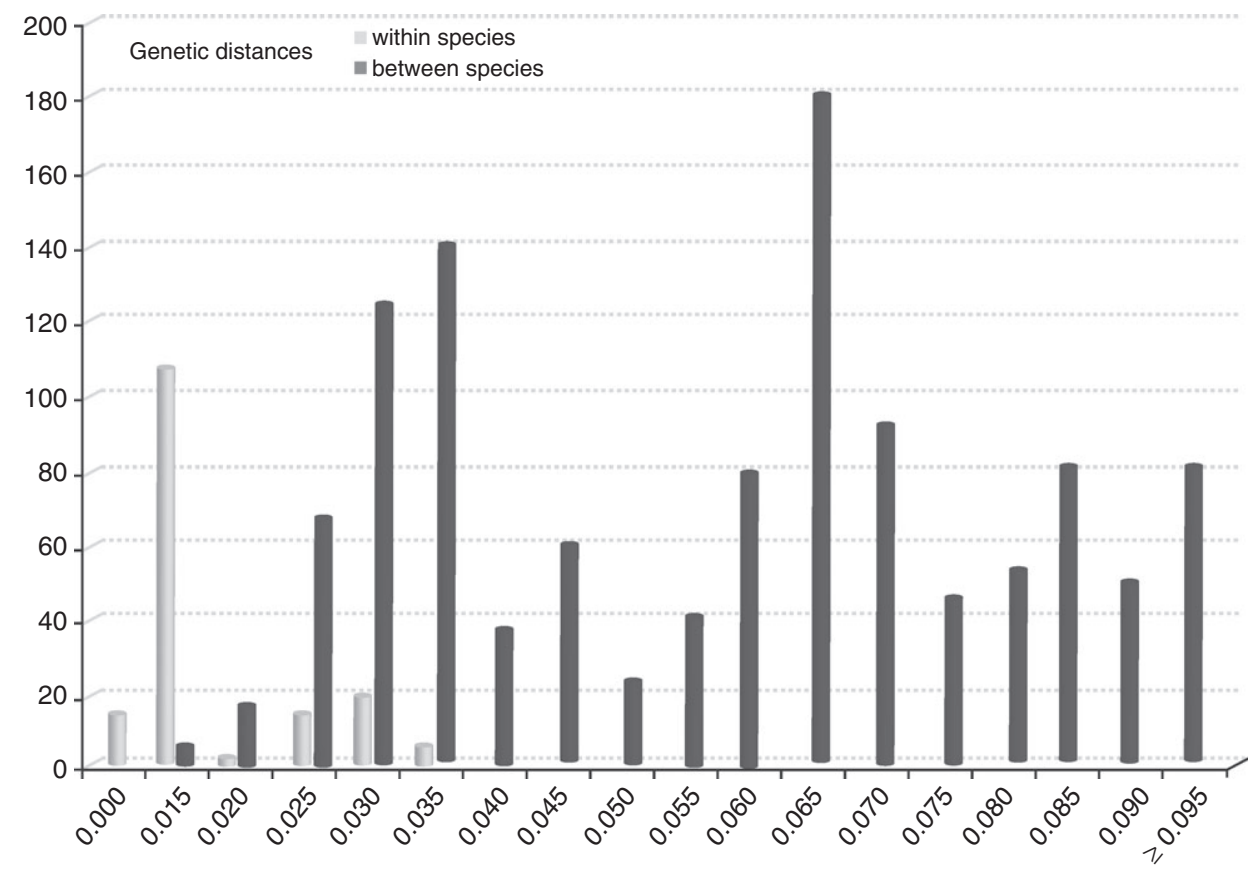

Fig. 2. Relationships among species of Eupholidoptera inferred from both Bayesian (A) and likelihood (B) analysis based on the three mitochondrial genes. Values above branches indicate bootstrap percentages for the maximum likelihood method and posterior probabilities derived from Bayesian analysis. Scale bars: 0.02 substitutions per site. Only posterior probability (PP) values $\geq 0.80$ and bootstrap values higher than $50 \%$ are shown.

in intraspecific comparisons and from 0.019 to 0.093 in interspecific ones (Fig. 3). The most differentiated species were E. megastyla, E. smyrnensis and E. uvarovi from Greece and Turkey, while, considering only the Italian species, the most differentiated species was the easternmost E. schmidti, which, in turn, was closely related to E. garganica. The taxa E.chabrieri, E.magnifica, E. bimucronata stat.n. and E.danconai were genetically closely related, with a mean genetic distance of 0.025 . However, genetic differentiation among these species was not homogeneous through the different populations; some genetic distance values were $<2 \%$ and some others $>3 \%$ (Fig. 3). Values $<2 \%$ concerned comparisons between E.chabrieri and the western Apennine species, as far as E.tyrrhenica sp.n. versus E. bimucronata stat.n. and E. magnifica versus E.danconai.

\section{Morphological analysis}

Concerning morphology, Italian Eupholidoptera are difficult to distinguish. Females are very uniform among species and generally can only be identified to species when males are also available. Conversely, identification of males is more straightforward. Morphometric measurements (total length, length of pronotum, length and height of hind femurs and length of ovipositor) of the taxa studied are reported in Table S3. Euclidean distances, based on morphometric variables (Table S4), showed significant differences among different taxa, confirming that measurements of specimens are good variables to identify taxa.

\section{Eupholidoptera chabrieri (Charpentier, 1825)}

This is one of the smallest species occurring in mediterranean France and northwestern Italy (Liguria, Piedmont and Lombardy). Tegmina are brownish, cerci are 1.5-1.6× longer than the tergum 10 . The subgenital plate of the male may have a small process with one or two spines, but generally only one spine is present (Fig. 6). Titillators in situ are short and just visible; they show a short and stout central body, ending with two short, parallel, well-separated and straight branches. In lateral view they appear just upcurved (Figs 4, 5). The subgenital plate of the female is longer than high (Fig. 39).

\section{Eupholidoptera brunneri (Targioni Tozzetti, 1881)}

We were unable to obtain molecular data for this taxon. It is the smallest Italian taxon in size within the genus; it is known only from Abruzzi (central Italy) (Fontana et al., 2004). The subgenital plate of the male bears a process that ends with a long spine (Fig. 9). Tegmina are blackish, cerci are $1.3-1.5 \times$ longer than tergum 10. Titillators are very similar to those of E. chabrieri, but are more slender, ending with two very short, divergent and straight branches, also in lateral view (Figs 7, 8). The subgenital plate of the female is clearly longer than high (Fig. 47).

\section{Eupholidoptera danconai La Greca, 1959}

This is a medium-sized Eupholidoptera that is recorded from Calabria through Campania and Latium to Marche, coastal Abruzzi and inner Tuscany. Tegmina are brownish, the subgenital plate of the male has very developed lobes, longer 

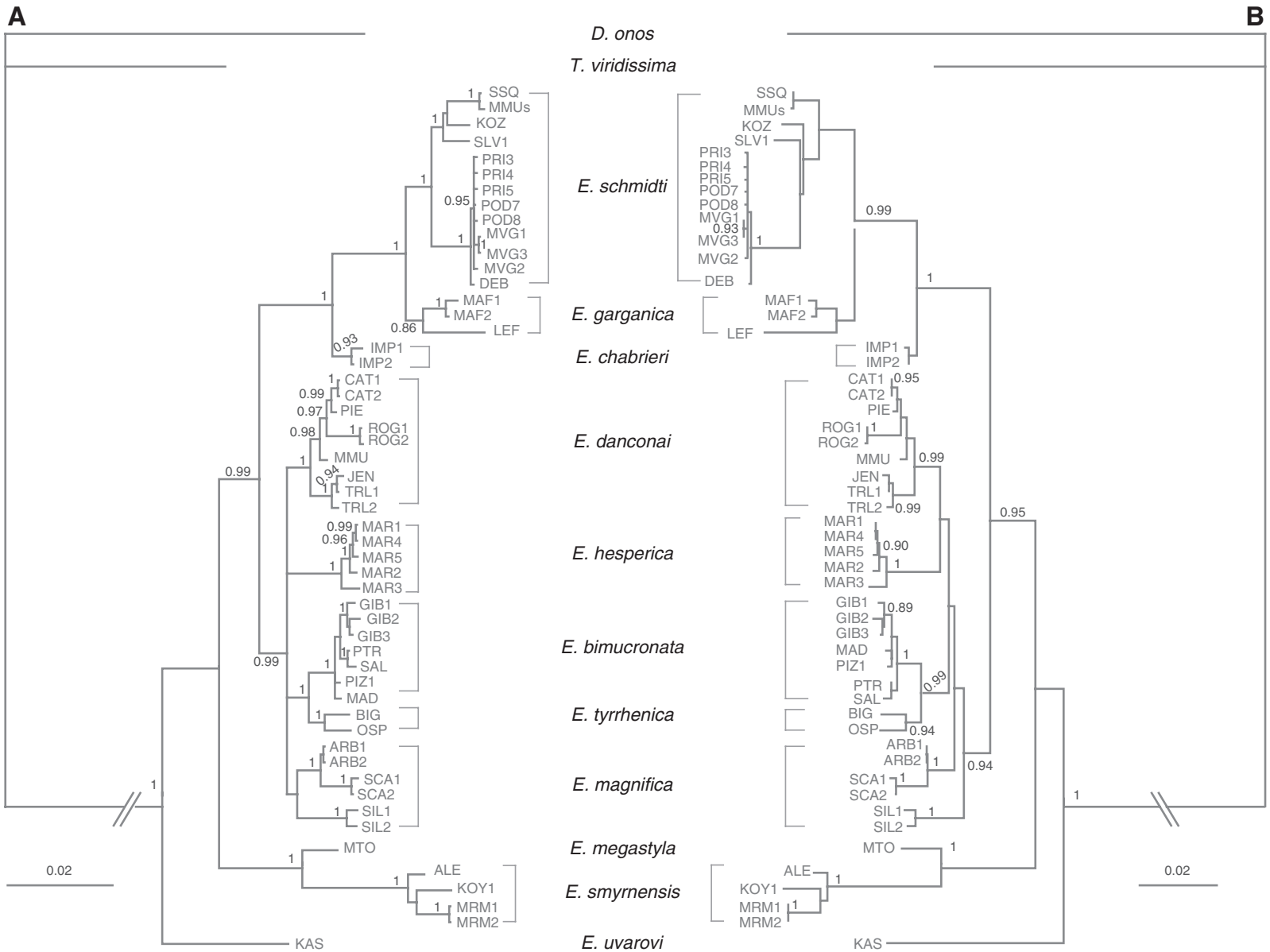

Fig. 3. Distribution of genetic distance values (p-distances) at different taxonomic levels. Pairwise comparisons at the intra- and interspecific level in the analysed Eupholidoptera species are reported.

than wide; at the apex they show a process that bears one long spine, sometimes paired with another very small one (Fig. 12). Styli are short. Cerci are $1.8-1.9 \times$ longer than tergum 10 . Titillators in situ are long and upcurved; they have contiguous and more or less parallel branches, apically just touching and small lateral wings; in lateral view they are upcurved. Titillators are always slender, mainly at their base (Figs 10, 11). The subgenital plate of female in lateral view is longer than high and apically rounded (Fig. 50).

\section{Eupholidoptera tyrrhenica sp.n.}

http://zoobank.org/urn:zoobank.org:act:AA921B7C-F3064 F17-8FDB-FEC90AA21435

Holotype male. FRANCE, Corsica, Ospedale, loc. Catalavonu (1000 m) 28.VIII.1995, leg. B. Massa. Depository. Museo Civico di Storia Naturale 'G. Doria', Genoa. Allotype and two paratypes. Same data as holotype. Depository. Coll. B. Massa, University of Palermo.

Description. Male. General habitus as other Eupholidoptera of the chabrieri-group. Head yellow with narrow lateral black markings behind antennae, and another larger black spot behind eyes. Face yellow with small black spots. Pronotum much longer than high, yellow with lateral black stripes and yellow lower borders. Tegmina short, just reaching first abdominal tergite, brown with lateral yellow stripe. Abdomen yellowish with some brown markings, tergum 10 black, ending with short and narrow semilunar concavity and pointed apices. Subgenital plate with short styles; upper base with process ending with one inner and a second outer (shorter) brown spine (Fig. 21). Cerci long, 1.9-2.1× length of tergum 10, black (Fig. 19). Antennae longer than entire body, exceeding tip of hind femurs. Fore and mid femurs yellow with black spots, hind femurs above yellow, with black lateral stripe and black marking on genicular lobe. Fore tibiae with six inner and outer lower spines and three outer upper spines, mid tibiae with six inner and outer lower spines and two inner and outer upper spines, hind tibiae with three or four inner and outer lower spines plus two apical spurs on each side, 21-23 inner and outer upper spines plus one apical spur on each side. Tarsi brownish. Titillators fine and slender, more robust at base of branches (Figs 19, 20). 




Figs. 4-15. Morphological characters of male Eupholidoptera chabrieri, E.brunneri, E. danconai and E. megastyla. Left: lateral view of last tergites and titillators in situ; centre: titillators; right: particular of last sternite, styli and spines. Arrows show diagnostic characters.

Female as male, with the following differences. Tegmina concealed below pronotum, only laterally visible behind it. Last tergite only laterally black, ovipositor yellow, gently upcurved. Subgenital plate in lateral view longer than high and clearly pointed at the apex (Fig. 49); view from below with welldeveloped V-shaped concavity.

Measurements. Total length: male $25.5+0.3 \mathrm{~mm}$, female 28.2 ; length of pronotum: male $10.0+0.1$, female 11.1 ; length of hind femurs: male $23.3+0.2$, female 26.1 ; height of hind femurs: male $4.3+0.1$, female 4.9 ; length of the ovipositor: 21.0.

Diagnosis. It is a medium-sized Eupholidoptera, characterized by long hind femurs and ovipositor, brown tegmina and by slender titillators, with branches parallel and well separated, gently upcurved in lateral profile.

Affinities. Material of this species has previously been identified as E.chabrieri, E.schmidti or E.magnifica, but the 

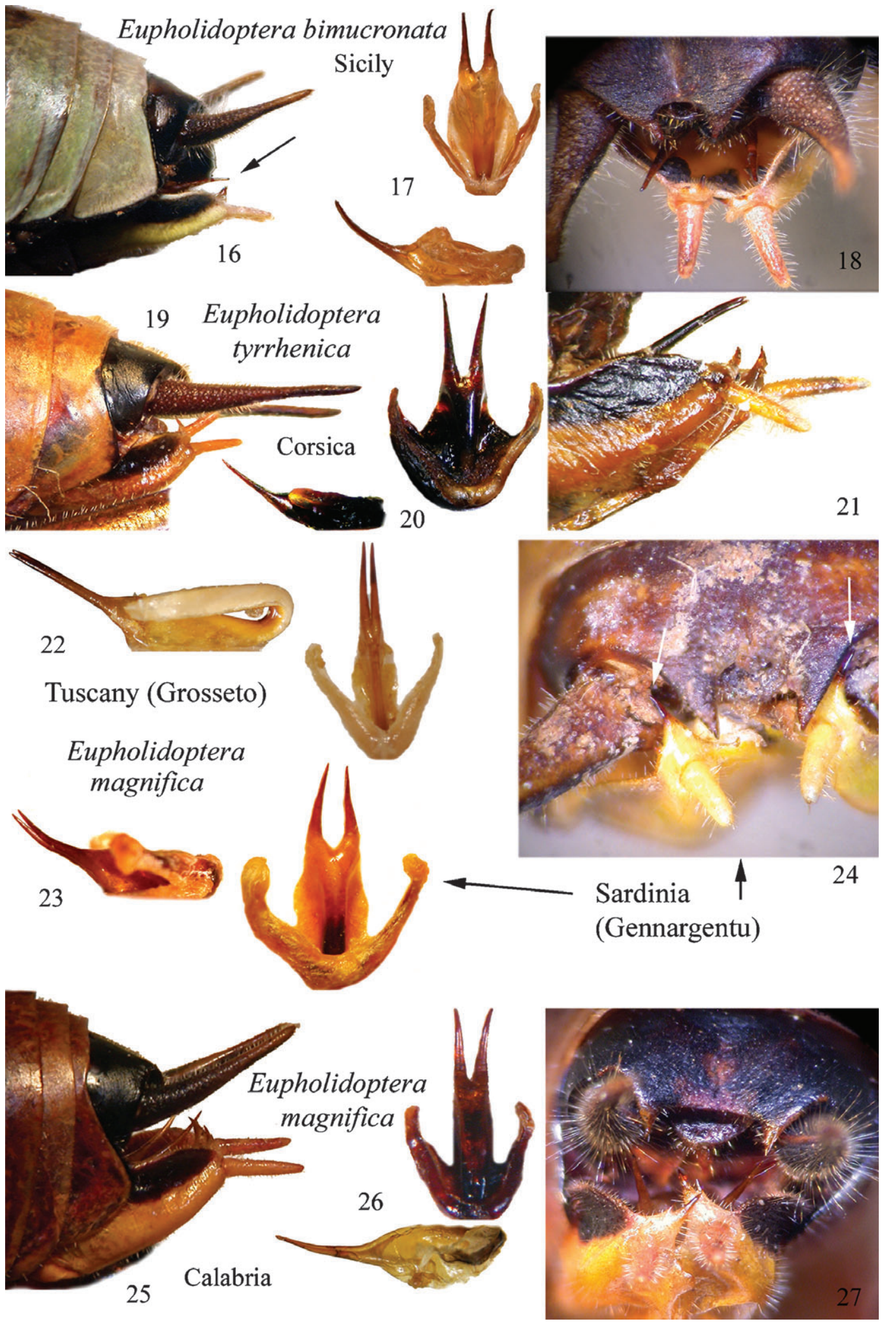

Figs. 16-27. Morphological characters of male Eupholidoptera bimucronata stat.n., E. tyrrhenica sp.n. and E. magnifica. Left: lateral view of last tergites and titillators in situ; centre: titillators; right: particular of last sternite, styli and spines. Arrows show diagnostic characters. 

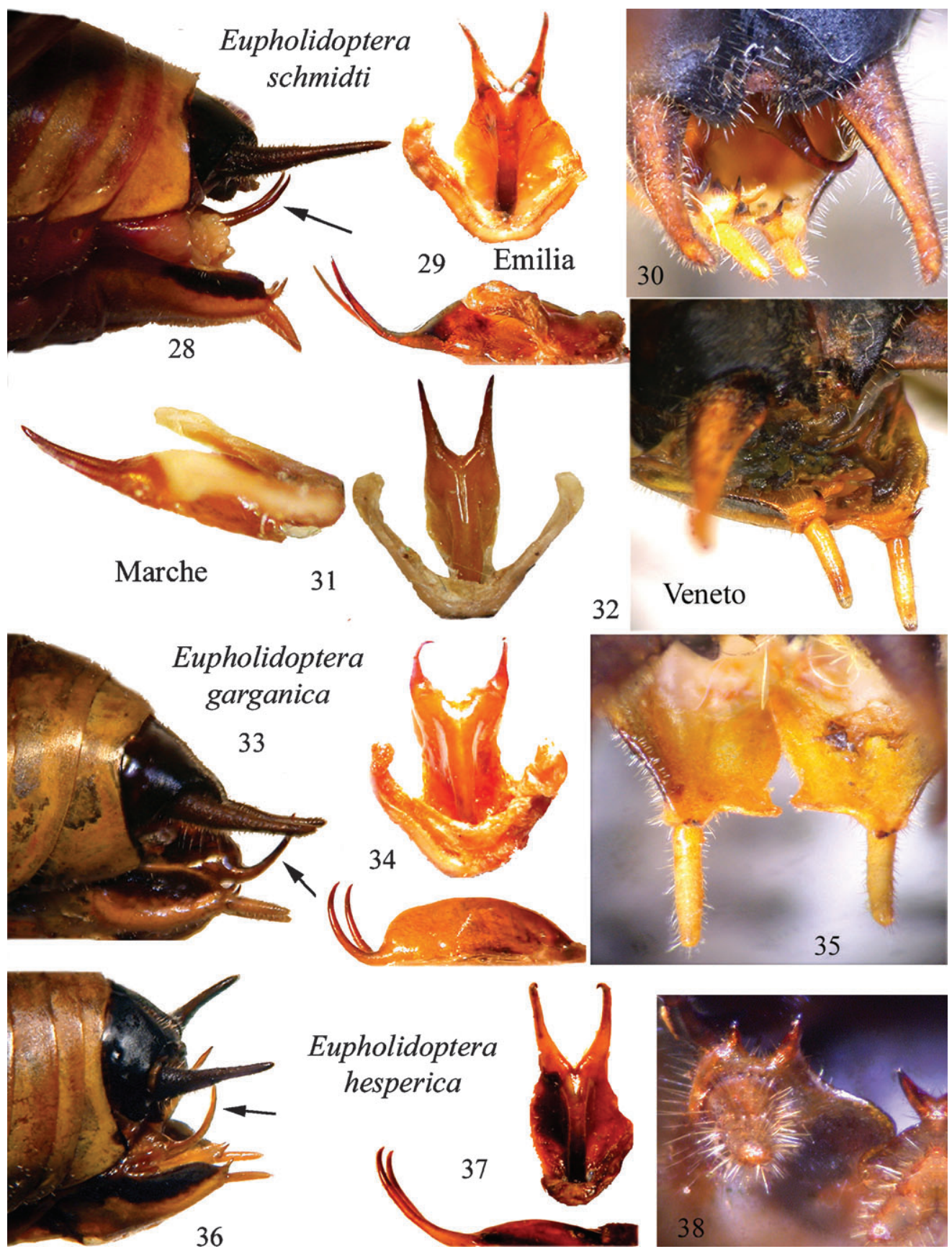

Figs. 28-38. Morphological characters of male Eupholidoptera schmidti, E. garganica and E. hesperica. Left: lateral view of last tergites and titillators in situ; centre: titillators; right: particular of last sternite, styli and spines. Arrows show diagnostic characters.

genetic and morphological differences we observed convinced us that it is a new taxon endemic to Corsica. Titillators are similar to those of E. magnifica; however, the central body is not as high as in E. magnifica, the branches are fine, parallel and well separated, gently upcurved in lateral view. Because of the similarity of titillators, Massa et al. (2012) considered E. magnifica widespread from south Italy to the Tyrrhenian coast, Sardinia and Corsica. Cerci are longer than in related species.
Etymology. From the Tyrrhenian sea area, which is adjacent to Corsica where this species occurs.

\section{Eupholidoptera magnifica (Costa, 1863)}

We agree with the opinion of La Greca (1959) and consider specimens examined by us from Sila (Calabria) and Campania as E. magnifica; it occurs also in Latium (Fanfani et al., 2006), coastal Tuscany and Sardinia. It is a medium-sized species, its 
39 Eupholidoptera chabrieri



41 Eupholidoptera schmidti Emilia

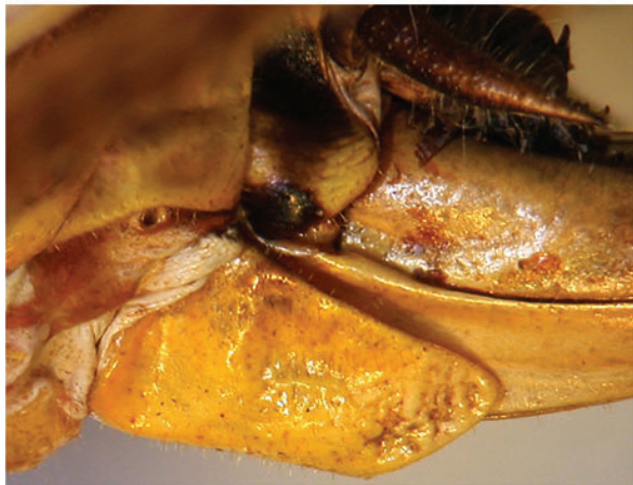

43 Eupholidoptera garganica Italy

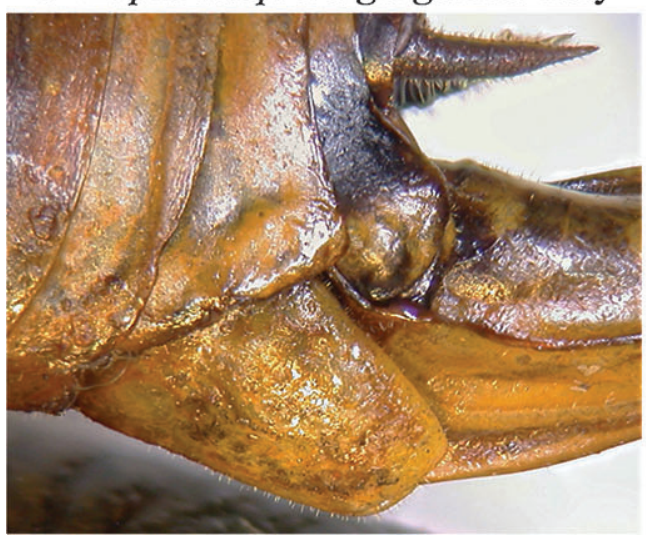

Eupholidoptera hesperica

40

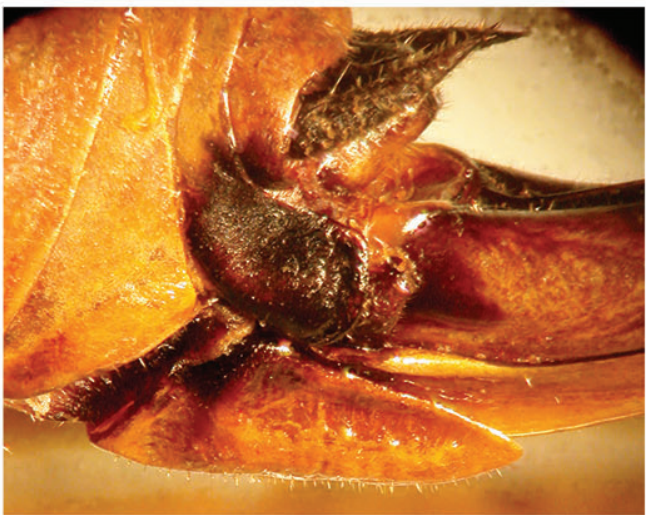

42 Eupholidoptera schmidti Albania

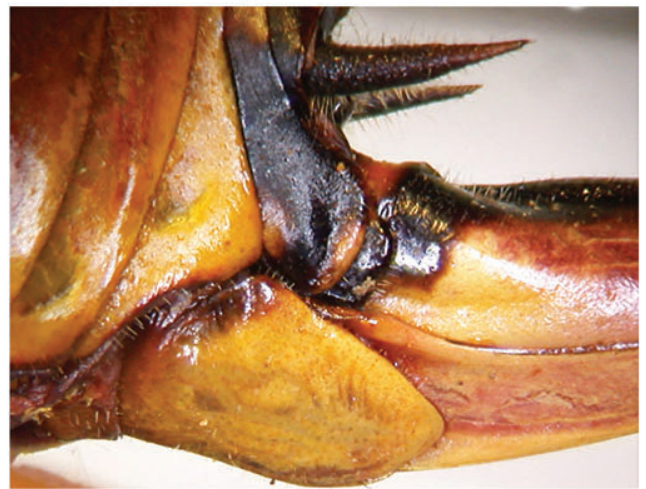

44 Eupholidoptera garganica Greece

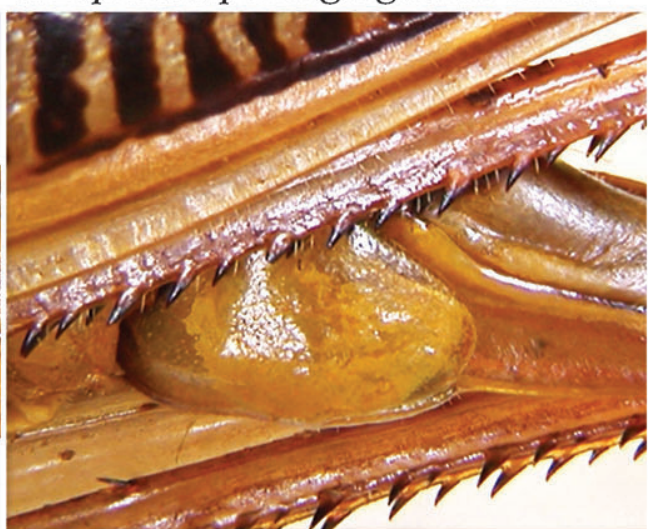

Figs. 39-44. Lateral view of the female subgenital plate of Eupholidoptera chabrieri, E. hesperica, E. schmidti and E. garganica from different regions.

titillators in situ are long and more or less gently upcurved; they show a narrow central body and long and divergent branches, just upcurved (Figs 25, 26). Lateral lamellar wings are lacking. Specimens from Tuscany and Sardinia show small differences in titillators (Figs 22, 23); even if they appear to be genetically related to E. magnifica from Calabria, they show small genetic distances that should justify their consideration as a separate subspecies. Tegmina may be brownish or black. The subgenital plate of the male shows a well-developed process that bears a long spine, at its base paired with another very small spine (Figs 24, 27). Cerci are $1.7-1.8 \times$ longer than tergum 10. The subgenital plate of the female in lateral view is as long as high and apically rounded. The upper valve of the ovipositor of Calabria specimens shows a basal black spot (Fig. 46). Specimens from Tuscany show a longer than high subgenital plate (Fig. 48). In addition the cluster analysis of measurements highlighted some differences among populations of this taxon (Table S4). 
45 Eupholidoptera bimucronata

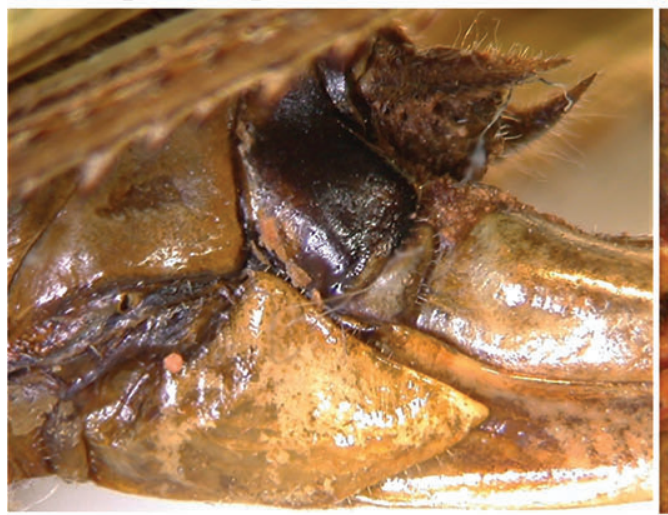

47 Eupholidoptera brunneri

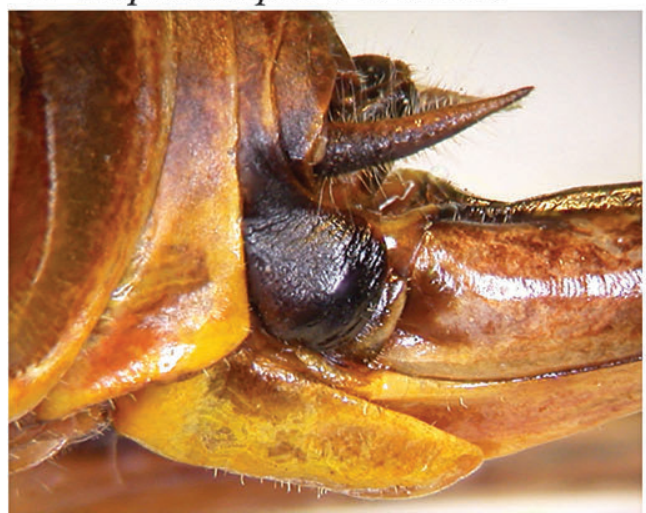

49 Eupholidoptera tyrrhenica Corsica

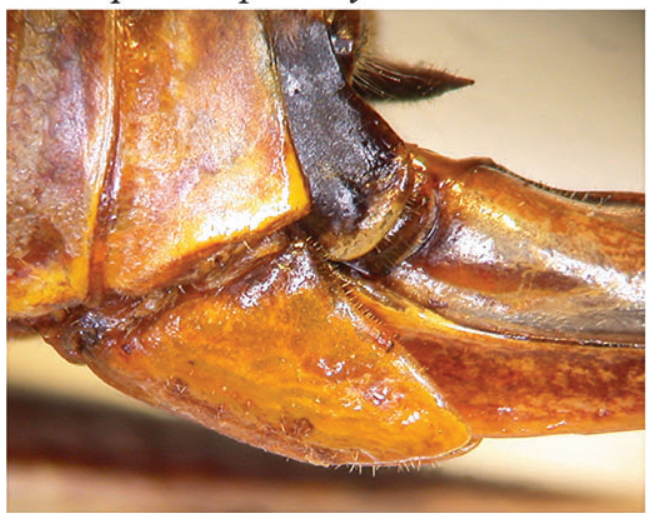

46 Eupholidoptera magnifica Calabria

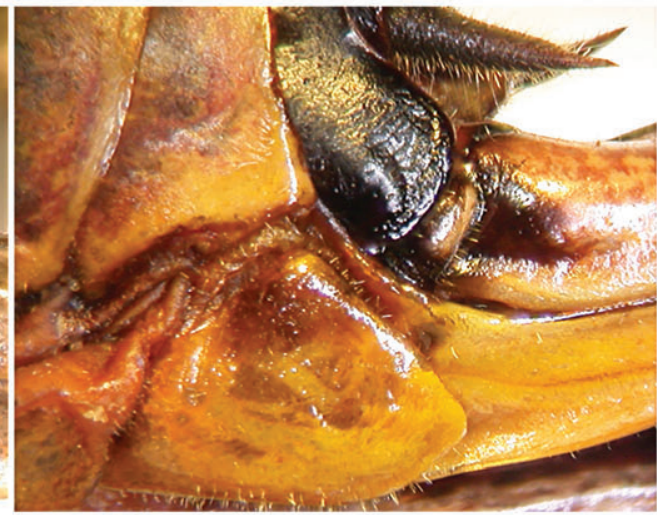

48 Eupholidoptera magnifica Tuscany

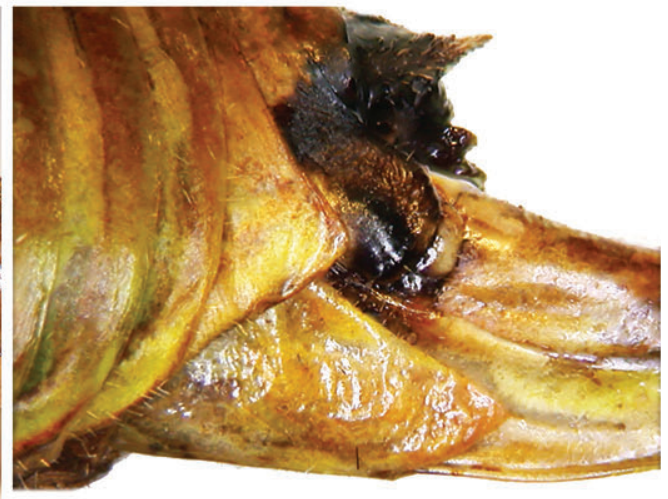

50 Eupholidoptera danconai

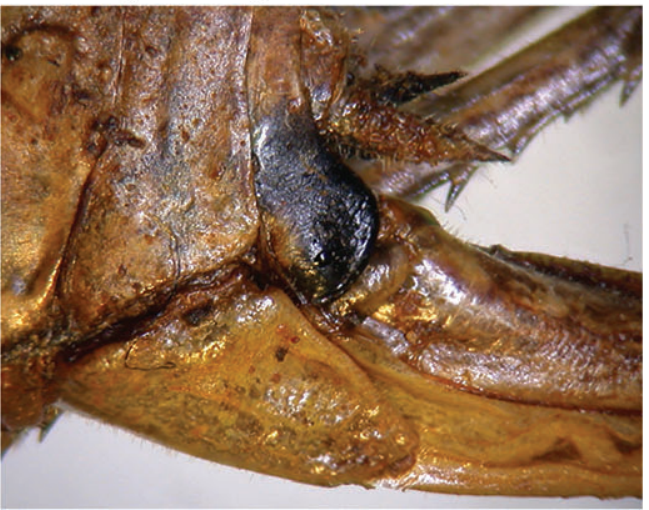

Figs. 45-50. Lateral view of the female subgenital plate of Eupholidoptera bimucronata stat.n., E. brunneri, E. magnifica (from Calabria and Tuscany), E. tyrrhenica sp.n. (from Corsica) and E. danconai .

\section{Eupholidoptera bimucronata stat.n. (Ramme, 1927)}

Small-sized taxon, endemic to Sicily. Titillators in situ are long and thin; they show a rather wide central body, as long as its final branches, that are long, fine and gently upcurved (Figs 16, 17). Tegmina are brown. The subgenital plate of the male may bear one or two small spines (from which the name bimucronata derived) (Fig. 18). Cerci are 1.5-1.6× longer than tergum 10. The subgenital plate of the female in lateral view is just longer than high and apically pointed (Fig. 45).

\section{Eupholidoptera schmidti (Fieber, 1861)}

Medium-sized species, that lives in the Balkan peninsula and north-east Italy (from Friuli to Emilia Romagna and Marche). Tegmina are black. It has elongate and more or less upcurved titillators having long, upcurved and well separated branches. Specimens from the Marche region (Italy) have less upcurved branches, while those from Veneto and Friuli regions (Italy), Albania and Greece have very upcurved and robust branches (Figs 28, 29, 31). Lateral lamellar wings are wide and well 


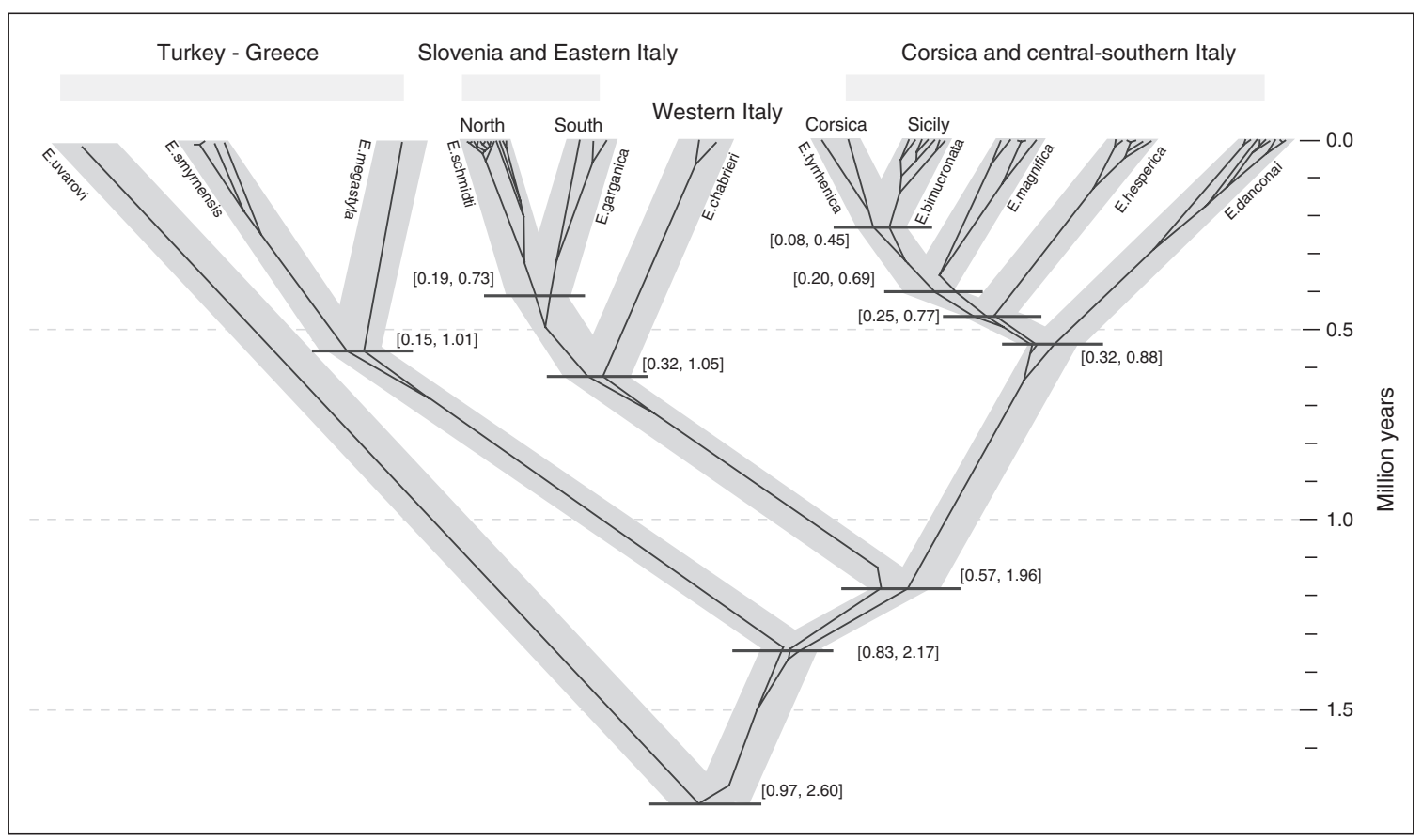

Fig. 51. Comparison between species tree (grey branches) and gene tree (black lines within grey branches) for Eupholidoptera species. Scale bar indicates the divergence times among species inferred by Bayesian analysis using relaxed molecular clocks. Bars at the nodes represent the 95\% highest posterior density (HPD) credibility interval in the species tree.

developed; the body of titillators is always robust, mainly at the base of branches. The subgenital plate of the male ends with a process that bears a couple of spines of different length (Figs 30, 32). Cerci are 1.5-1.9× longer than tergum 10 (Fig. 28 ). The subgenital plate of the female in lateral view is longer than high and apically more or less rounded (both in Italian and Balkan populations) (Figs 41, 42).

\section{Eupholidoptera garganica La Greca, 1959}

This is a large species that occurs in western Greece (Epirus) and a small part of south-east Italy (Apulia). Tegmina are black. Titillators are evidently upcurved; they consist of a wide body, lacking lateral wings, laterally compressed, longer than wide and dorsally convex. Branches are very short and sharply upcurved (Figs 33, 34). The subgenital plate of the male has two very short spines, of different length, but lacks the apical process that in other taxa bears them (Fig. 35). Cerci are $1.3-2.0 \times$ longer than tergum 10 . The subgenital plate of the female in lateral view is slightly longer than high and apically rounded (Greek population) or truncated (Italian population) (Figs 43, 44).

\section{Eupholidoptera hesperica La Greca, 1959}

This is a medium-sized species known only from Basilicata and Campania in Italy. Tegmina are brownish. Titillators in situ are very upcurved and thin; they show a very short central body, with very long branches, upcurved and apically convergent; apical arms of titillators have a robust fused basal part and long unfused apical parts, and very narrow or lacking wing-like lateral expansions (Figs 36, 37). The subgenital plate has no apical process and may lack spines; if present, they are not placed together, but one on the right and the other on the left of the upper stylus base (Fig. 38). Cerci are 1.4-1.6× longer than tergum 10. The subgenital plate of the female is much longer than high and apically pointed (Fig. 40).

\section{Discussion}

Genetic diversity in Italian Eupholidoptera species and their taxonomic relationships

The Italian Eupholidoptera species group comprises a taxonomically diverse assemblage of species with different levels of differentiation, both genetically and morphologically. Genetic distance values based on coxl suggested that E. schmidti, E. garganica and E. hesperica are the most differentiated species, showing a mean sequence divergence ranging from $2.8-6.5 \%$ between one another and between each of them and the other taxa included. The western and Apennine group of species showed genetic distance values both overlapping those of conspecific comparisons (Fig. 3) and/or coincident with the threshold usually considered in interspecific comparisons ( $\geq 3 \%$, Hebert et al., 2003). In particular, E. chabrieri appears to be the least differentiated species with genetic distance values ranging from 1.9 to $2.6 \%$. These results suggest that the Italian Eupholidoptera are constituted by both 
recently (i.e. originated probably during the Pleistocene) and less recently diverged species. Indeed, phylogenetic reconstruction, using all the three mitochondrial genes analysed in this study, points out the existence of well-differentiated clusters corresponding to the species recognised using morphological characters. These results suggest that DNA barcoding is not informative about the species status when recently diverged species are compared, confirming that identification of species based on exclusivity criteria can be incongruent with species identification using other sources of data and that the use of thresholds applied to genetic data may be problematic (Takahata \& Nei, 1985; Hudson \& Coyne, 2002; Hudson \& Turelli, 2003; Moritz \& Cicero, 2004; Matz \& Nielsen, 2005). It is also problematic to use only a single genetic marker, especially when recently diverged species are considered. In such cases molecular characters may show low levels of differentiation (de Queiroz, 2005). Indeed, considering all the three analysed genes, mean sequence divergence increases up to $4 \%$ when comparisons within the western and the Apennine group of species are considered (data not shown).

The analysed species present a disjunct distribution, as outlined in the results section, and some of them are sympatric in particular regions. This is the case of Monte Murano (MMUd and MMUs; Fig. 1), where a population of E. schmidti is sympatric with one of E.danconai. The two populations are morphologically distinguishable and genetically well differentiated. This result suggests that DNA barcode is a powerful tool when well-differentiated species are compared, even if we recognise that a molecular approach to the delimitation of species may underestimate diversity when quickly and recently evolving species are considered.

The topology in Fig. 2 shows that phylogenetically close taxa are not geographically close. The trees show two main Italian groups, one including the eastern species and the other one the Apennine and the western species. The first group is represented by E. schmidti and E. garganica. Eupholidoptera schmidti occurs in the Balkan peninsula and in north-east Italy, while E. garganica is present in Apulia (south-east Italy) and in Epirus (northwest Greece), where the two distribution ranges overlap, E. garganica is sympatric with E. schmidti in some localities (Willemse, 1980). Our genetic data show that they are different species and differentiated from E. chabrieri, which is placed as their sister group (Fig. 2). Morphologically E. schmidti is closely related to E. garganica and the identification of both taxa is difficult (Willemse, 1980). On the one hand, based on these observations and considering that intermediate forms of 'E. garganica' and Balkan 'E.chabrieri' occur in Slovenia, Croatia and Albania, Willemse (1980) and Çiplak et al. $(2007,2009,2010)$ regarded E. garganica as a subspecies of E. chabrieri. On the other, Massa (1999) hypothesised a separation at species level by considering just the contiguity and overlap of E. garganica and E. schmidti in Greece. Taxa geographically overlapping that we may assume do not exchange genetic material can be considered as separate species. In some cases they show very distinctive characters, and it is thus justifiable to raise them to species level. This hypothesis seems to be supported by mitochondrial DNA analysis that allows to disprove the hypothesis of Çiplak et al. $(2007,2009)$ that both E. schmidti and E. garganica are synonyms of E. chabrieri.

The second group of Italian species in Fig. 2, well supported by both PP and BP values, is constituted by five well-supported clades, each corresponding to a different species: E. danconai, E. hesperica, E. bimucronata stat.n., E.tyrrhenica sp.n. and E.magnifica, confirming the species status of Corsican (E.tyrrhenica sp.n.), Sicilian (E.bimucronata stat.n.) and central-south Italian (E.danconai) populations. However, their relative relationships were unresolved both in Bayesian and likelihood analyses. This may be due to a nearly simultaneous origin of some lineages, indicated by comparatively short internodes.

Figure 51 shows the gene tree embedded in the species tree (see Material and Methods for details). The two trees, given the new scenario for the delimitation of species described in this paper, are in agreement. Both trees emphasise a close affinity between the geographically distant populations of Corsica and Sicily, probably due to retention of ancestral polymorphism by genetic drift. Alternatively, hybridisation could have occurred during periods of Eupholidoptera range expansion allowing mtDNA transfer between populations that have previously diverged in allopatry.

A complex taxonomic situation concerns E.danconai that Willemse (1980) synonymised with the Greek E. megastyla, based on morphological characters. In particular, in E.megastyla the process at the base of styli is prominent and bears a long spine, styli are longer than in related taxa (Fig. 15). These two species have titillators with very close branches, but they are very fine and straight in E.megastyla (Figs 13, 14), while in E.danconai they are upcurved and not contiguous (Figs 10, 11). Results from mitochondrial DNA analysis definitely reject the hypothesis that E. megastyla is a senior synonym of E.danconai. Indeed, the Greek species in Fig. 2 is excluded from the Italian clade and both Bayesian and likelihood analyses highly support the node linking all the Italian species together.

These results seem to contradict the hypothesis of Çiplak et al. (2010). According to these authors, the E.chabrieri group is supported by unique synapomorphies, all of which belong to the male subgenital plate. The quadrangular apical lobes and the depth of its incision are unique and shared by all species in this group. Based on these observations Çiplak et al. (2010) argue for the existence of a single species in the western Mediterranean (plus E. hesperica). Based on our results, many differences exist in the male subgenital plate of taxa here considered and therefore we can consider them as belonging to the same group of species but not to the same species. In conclusion mitochondrial DNA analysis supports the hypothesis of Massa et al. (2012), who have considered most of the Italian Eupholidoptera taxa as different species.

\section{Divergence times}

The reliability of molecular rate estimates depend strongly on the accuracy by which genetic variation is estimated and 
on the appropriateness of the calibration method (Arbogast et al., 2002; Bromham \& Penny, 2003). Methods for estimating evolutionary timescales from DNA sequence data have become increasingly important over the past few decades (Kumar, 2005; Hedges \& Kumar, 2009) and the choice of calibration events is crucial to the accuracy of molecular dating. Although in our taxa insular species of Eupholidoptera are represented, the recurrent occasions for isolation and dispersal occurred during the Plio-Pleistocene make it difficult to trace a particular calibration event. Therefore, rather than take advantage of palaeogeographic information to calibrate the molecular clock, we decided to use molecular rates previously calculated for Orthoptera in cox1, 12S and $16 S$ genes (Shapiro et al., 2006; Allegrucci et al., 2011). By this procedure, we attempted to consider geological and palaeoclimatic scenarios for speciation as dependent variables, rather than predetermined bases for calibration.

Following Çiplak et al. (2010), all taxa present in Italy are closely related to Greek species, the latter having diverged first in the E. megastyla subgroup. The tree topology and estimated divergence time (Fig. 51) argue for an early Pleistocene deep cladogenesis of the Italian Eupholidoptera species and agree with Çiplak et al. (2010) for a Greek origin of the two main lineages in Fig. 2. The estimated divergence time of the Italian lineages from the Greek ones spans from 1.1 to $2.6 \mathrm{Ma}$ $(95 \%$ HPD, mean $=1.7 \mathrm{Ma}$; Fig. 51). These events date back to the Plio-Pleistocene era, when repeated changes between marine regression and transgressions of the Ionian/Adriatic areas might have favoured dispersal and allopatric separation of the lineages. Our data support the hypothesis of a direct faunal connection between continental Greece and Italy, as suggested by previous authors (e.g., La Greca, 1959). This hypothesis was based on the observation of both the absence of endemic taxa in France, Switzerland, north-west Balkans and west Mediterranean islands, and the presence of Greek species quite similar to the Italian ones. Therefore, the westward dispersal from Greece could have taken place before the regression of the Ionian/Adriatic areas during the Pliocene, and during the Pleistocene. Based on present data, the main movement of Balkan 'chabrieri' group occurred in the Pleistocene through north-east Italy. An ancestral group of E.chabrieri isolated from Balkan populations and spread through the inland of Italian Peninsula and westwards to Mediterranean France.

The subsequent isolation and speciation of the two main Italian species groups date back to $1.2 \mathrm{Ma}(95 \%$ $\mathrm{HPD}=0.6-1.9 \mathrm{Ma}$, Fig. 51), while the divergence within each group spans from 0.3 to $1.0 \mathrm{Ma}(95 \% \mathrm{HPD}$, mean $=0.6 \mathrm{Ma}$ in the western lineage and 0.65 in the eastern one). These estimates again date back to the Pleistocene when populations experienced repeated instances of active dispersal during interglacial periods, alternating with episodes of population fragmentation and reduction of gene flow during the dry cold climatic phases. Groups of marginal populations could have become isolated at different times, due to the marked climatic and vegetation changes which have occurred since the Pliocene. Interestingly, a comparable time of divergence was hypothesised for evolutionary splitting of the Italian cave crickets belonging to the genus Dolichopoda (Allegrucci et al., 2005), showing the same distribution pattern of Eupholidoptera in the Mediterranean region. Also in this case colonization of western Mediterranean probably arose from the north-east Italy during the middle/late Pliocene (Allegrucci et al., 2009, 2011).

In conclusion, our data suggest that speciation events have been strictly allopatric, as also supported by the weak mechanisms of reproductive isolation, demonstrated by Lemonnier-Darcemont (2007) who obtained in laboratory vital and fertile crossbreds between E. chabrieri from France and E. schmidti from Greece.

\section{Supporting Information}

Additional Supporting Information may be found in the online version of this article under the DOI reference:

10.1111/syen. 12031

Table S1. Eupholidoptera specimens used for the molecular analysis.

Table S2. Novel specific primers used in this study.

Table S3. Morphometric measurements in Italian Eupholidoptera taxa (mean $+\mathrm{SD})$.

Table S4. Euclidean distances among different taxa of Eupholidoptera, obtained by cluster analysis of morphometric variables. n.a., not available (insufficient sample).

File S1. Details of specimens collected for morphological and molecular analyses.

\section{Acknowledgements}

We are indebted to the following colleagues who permitted us to examine preserved material: Roberto Poggi (Baccetti and Capra's collections, Museo Civico di Storia Naturale 'G. Doria' of Genoa) Maurizio Pavesi and Fabrizio Rigato (La Greca's collection, Museo Civico di Storia Naturale of Milan), Augusto Vigna Taglianti (Salfi's collection, Museo di Zoologia of the Rome La Sapienza University), Paolo Fontana (coll. P. Fontana, Isola Vicentina). We are grateful to Camillo Cusimano, for his statistical suggestions and to Gabriele Gentile for his constructive criticisms. We also thank Augusto Cattaneo, Salvatore Blando, Gianfranco Bologna, Giovanni Carotti, Camillo Cusimano, Luca Fancello, Stanislav Gomboc, Carmine Iorio, Ippolita Petretti, Francesco Petretti, Ignazio Sparacio and Marcello Tagliavia, who sent us several specimens from Italy, Turkey and Balkans. Finally, we thank three anonymous referees and Lars Vilhelmsen for their useful suggestions.

\section{References}

Allegrucci, G., Todisco, V. \& Sbordoni, V. (2005) Molecular phylogeography of Dolichopoda cave crickets (Orthoptera, Rhaphidophoridae): a scenario suggested by mitochondrial DNA. Molecular Phylogenetics and Evolution, 37, 153-164. 
Allegrucci, G., Rampini, M., Gratton, P., Todisco, V. \& Sbordoni, V. (2009) Testing phylogenetic hypotheses for reconstructing the evolutionary history of Dolichopoda cave crickets in the eastern Mediterranean. Journal of Biogeography, 36, 1785-1797.

Allegrucci, G., Trucchi, E. \& Sbordoni, V. (2011) Tempo and mode of species diversification in Dolichopoda cave crickets (Orthoptera, Rhaphidophoridae). Molecular Phylogenetics and Evolution, 60, $108-121$.

Arbogast, B.S., Edwards, S.V., Wakeley, J., Beerli, P. \& Slowinski, J.B. (2002) Estimating divergence times from molecular data on phylogenetic and population genetics timescales. Annual Review of Ecology and Systematics, 33, 707-740.

Baccetti, B. (1959) Notulae orthopterologicae XIII: indagini sugli Ortotteroidei della Maiella per il Centro di Entomologia agraria alpina e forestale del CNR. Redia, 44, 245-306.

Bromham, L.D. \& Penny, D. (2003) The modern molecular clock. Nature, 4, 216-224.

Çiplak, B., Willemse, F., Chobanov, D. \& Heller, K.G. (2007) Systematic status and distribution of Eupholidoptera (Orthoptera: Tettigoniidae) in the Balkans (north of Central Greece). Articulata, 22, 33-46.

Çiplak, B., Heller, K.G. \& Willemse, F. (2009) Review of the genus Eupholidoptera (Orthoptera, Tettigoniidae): different genitalia, uniform song. Zootaxa, 2156, 1-75.

Çiplak, B., Heller, K.G. \& Willemse, F. (2010) Phylogeny and biogeography Eupholidoptera Mařan (Orthoptera, Tettigoniidae): morphological speciation in correlations with the geographical evolution of the eastern Mediterranean. Systematic Entomology, 35, $722-738$.

Costa, A. (1863) Nuovi studi di entomologia della Calabria ulteriore. Atti Reale Accademia delle Scienze Fisiche e Matematiche di Napoli, 2, $80 \mathrm{pp}$.

Drummond, A.J. \& Rambaut, A.J. (2007) BEAST v1.4.7. Bayesian Evolutionary Analysis Sampling Trees Computer Program [WWW document]. URL http://beast.bio.ed.ac.uk [accessed on 20 September 2012].

Drummond, A.J., Ho, S.H.W., Phillips, M.J. \& Rambaut, A. (2006) Relaxed phylogenetics and dating with confidence. PLoS Biology, 4, 699-710.

Ebner, R. (1915) Zur Kenntnis der Orthopterenfauna der Abruzzen. Deutsche Entomologische Zeitschrift Berlin, 1915, 545-570.

Edwards, S.V. (2009) Is a new and general theory of molecular systematics emerging? Evolution, 63, 1-19.

Fanfani, A., Nardi, G., Folletto, A. \& Tinelli, A. (2006) Il sistema ambientale della Tenuta Presidenziale di Castelporziano. Ricerche sulla complessità di un ecosistema forestale costiero mediterraneo. Accademia Nazionale delle Scienze, detta dei Quaranta, Scritti e Documenti, 37, 1609-1846.

Felsenstein, J. (1981) Evolutionary tree from DNA sequences: a maximum likelihood approach. Journal of Molecular Evolution, 17, $368-376$.

Folmer, O., Black, M.B., Hoch, W., Lutz, R.A. \& Vrijehock, R.C. (1994) DNA primers for amplification of mitochondrial Cytochrome c Oxidase subunit I from diverse metazoan invertebrates. Molecular Marine Biology and Biotechnology, 3, 294-299.

Fontana, P., Buzzetti, F.M., Tollis, P. \& Vigna Taglianti, A. (2004) The orthopteroid insects of the Abruzzo, Lazio and Molise National Park and surrounding localities (Central Apennine, S Italy) (Blattaria, Mantodea, Orthoptera, Phasmatodea, Dermaptera). Memorie della Società Entomologica Italiana, 82, 557-614.

Fontana, P., La Greca, M. \& Kleukers, R. (2005) Insecta Orthoptera. Checklist e distribuzione della Fauna italiana (ed. by S. Ruffo \& F. Stoch) (with CD-rom). Memorie Museo Civico di Storia Naturale, Verona, 2 a Serie, Scienze della Vita, 16, 137-139.
Friedrich, M. \& Tautz, D. (1997) An episodic change of rDNA nucleotide substitution rate has occurred during the emergence of the insect order Diptera. Molecular Biology and Evolution, 14, 644-653.

Hadley, A. (2008) Combine $Z$ [WWW document]. URL www.hadleyweb.pwp.blueyonder.co.uk [accessed on 10 February 2009].

Harz, K. (1969) The Orthoptera of Europe. I. Junk, The Hague.

Hebert, P.D.N., Cywinska, A., Ball, S. \& de Waard, J.R. (2003) Biological identifications through DNA barcodes. Proceedings of the Royal Society of London, Series B, 270, 313-321.

Hedges, S.B. \& Kumar, S. (2009) Discovering the timetree of life. The Timetree of Life (ed. by S.B. Hedges \& S. Kumar), pp. 3-18. Oxford University Press, New York, NY.

Heled, J. \& Drummond, A.J. (2010) Bayesian inference of species trees from multilocus data. Molecular Biology and Evolution, 27, 570-580.

Heller, K.G. (2006) Song evolution and speciation in bushcrickets. Insect Sounds and Communication: Physiology, Behaviour, Ecology and Evolution (ed. by S. Drosopoulos \& M.F. Claridge), pp. 137-151. CRC Taylor \& Francis, Boca Raton, FL.

Hudson, R.R. \& Coyne, J.A. (2002) Mathematical consequences of the genealogical species concept. Evolution, 56, 1557-1565.

Hudson, R.R. \& Turelli, M. (2003) Stochasticity overrules the "threetimes" rule: genetic drift, genetic draft, and coalescence times for nuclear loci versus mitochondrial DNA. Evolution, 57, 182-190.

Huelsenbeck, J.P. \& Ronquist, F. (2001) MrBayes: bayesian inference of phylogenetic trees. Bioinformatics, 17, 754-755.

Jobb, G., von Haeseler, A. \& Strimmer, K. (2004) TREEFINDER: a powerful graphical analysis environment for molecular phylogenetics. BMC Evolutionary Biology, 4, 18-27.

Knowles, L.L. \& Carstens, B.C. (2007) Delimiting species without monophyletic gene trees. Systematic Biology, 56, 887-895.

Knowles, L.L. \& Kubatko, L.S. (2010) Estimating species trees: an introduction to concepts and models. Estimating Species Trees: Practical and Theoretical Aspects (ed. by L.L. Knowles \& L.S. Kubatko), pp. 1-14. Wiley-Blackwell, Hoboken, New Jersey.

Kocher, T.D., Thomas, W.K., Meyer, A., Edwards, S.V., Pääbo, S., Villablanca, F.X. \& Wilson, A.C. (1989) Dynamics of mitochondrial DNA evolution in animals: amplification and sequencing with conserved primers. Proceedings of the National Academy of Sciences of the United States of America, 86, 6196-6200.

Kumar, S. (2005) Molecular clocks: four decades of evolution. Nature Reviews Genetics, 6, 654-662.

La Greca, M. (1959) L'Ortotterofauna pugliese ed il suo significato biogeografico. Memorie di Biogeografia Adriatica, 4, 31-170.

Lemonnier-Darcemont, M. (2007) Eupholidoptera chabrieri schmidti (Fieber, 1861) (Orthoptera, Tettigoniidae), un statut à debattre? Biocosme Mésogéen, Nice, 24, 9-14.

Lunt, D.H., Zhang, D.X., Szymura, J.M. \& Hewitt, G.M. (1996) The insect cytochrome oxidase I gene: evolutionary patterns and conserved primers for phylogenetic studies. Insect Molecular Biology, 5, 153-165.

Maddison, W.P. (1997) Gene trees in species trees. Systematic Biology, 46, 523-536.

Mařan, J. (1953) Contribution to the knowledge of the genus Pholidoptera Wesm. Acta Entomologica Musei Nationalis Pragae, 27, 209-221.

Massa, B. (1999) Ortotteri dell' area mediterranea e delle isole Azzorre nuovi o poco noti (Insecta). Atti della Accademia Roveretana degli Agiati, 249, 57-80.

Massa, B., Fontana, P., Buzzetti, F.M., Kleukers, R. \& Odé, B. (2012) Fauna d'Italia. Orthoptera, Vol. 48. Calderini, Bologna. 
Matz, M.V. \& Nielsen, R. (2005) A likelihood ratio test for species membership based on DNAsequence data. Philosophical Transactions of the Royal Society of London, Series B, 360, 1969-1974.

Moritz, C. \& Cicero, C. (2004) DNA barcoding: promise and pitfalls. PLoS Biology, 2, 1529-1531.

Nadig, A. (1985) Taxonomie und Verbreitung der Eupholidoptera chabrieri-unterarten (Orthoptera) am Südrand der Alpen, im Karst, auf den Inseln der nordlichen Adria und in den Abruzzen (auf grund morphometrischer untersuchungen). Atti della Accademia Roveretana degli Agiati, 24, 159-188.

Nylander, J.A.A. (2004) MrModeltest v.2. Program Distributed by the Author. Evolutionary Biology Centre, Uppsala University, Uppsala.

De Queiroz, K. (2005) Different species problems and their solution. BioEssays, 26, 67-70.

Rambaut, A. \& Drummond, A.J. (2007) Tracer v.1.5 (Computer Program) [WWW document]. URL http://evolve.zoo.ox.ac.uk/Evolve/ Software.html [accessed on 20 September 2012].

Ramme, W. (1927) Die Dermapteren und Orthopteren Siziliens und Kretas. Eos, 3, 111-200.

Ramme, W. (1939) Beiträge zur Kenntnis der palaearktischen Orthopterenfauna (Tettig. u. Acrid.) III. Mitteilungen aus dem Zoologischen Museum in Berlin, 24, 41-150.

Ramme, W. (1951) Zur Systematik, Faunistik und Biologie der Orthopteren von Südost-Europa und Vorderasien. Mitteilungen aus dem Zoologischen Museum in Berlin, 27, 1-431, 39Pl.
Shapiro, L.H., Strazanac, J.S. \& Roderick, G.K. (2006) Molecular phylogeny of Banza (Orthoptera: Tettigoniidae), the endemic katydids of the Hawaiian Archipelago. Molecular Phylogenetics and Evolution, 41, 53-63.

Simon, C., Frati, F., Beckenbach, A., Crespi, B., Liu, H. \& Flook, P. (1994) Evolution, weighting, and phylogenetic utility of mitochondrial gene sequences and a compilation of conserved polymerase chain reaction primers. Annals of the Entomological Society of America, 87, 651-701.

Takahata, N. \& Nei, M. (1985) Gene genealogy and variance of interpopulational nucleotide differences. Genetics, 110, 325-344.

Targioni Tozzetti, A. (1881) Orthopterorum Italiae species novae in collectione R. Musei Fiorentini digestae. Bullettino della Società Entomologica Italiana, Firenze, 13, 180-186.

Thompson, J.D., Gibson, T.J., Plewniak, F., Jeanmougin, F. \& Higgins, D.G. (1997) The ClustalX windows interface: flexible strategies for multiple sequence alignment aided by quality analysis tools. Nucleic Acids Research, 24, 4876-4882.

Willemse, F. (1980) Classification and distribution of the species of Eupholidoptera Ramme in Greece (Orthoptera, Tettigonioidea, Decticinae). Tijdschrift voor Entomologie, 123, 39-69.

Zhou, Z., Huang, Y., Shi, F. \& Ye, H. (2009) The complete mitochondrial genome of Deracantha onos (Orthoptera: Bradyporidae). Molecular Biology Report, 36, 7-12.

Accepted 20 June 2013 